\title{
Service-Learning Collaboration: Improving Teachers' Critical-Thinking and Job-Skill Training Using Active Simulation
}

\author{
Larry P. Nelson \\ University of Texas at Arlington
}

\begin{abstract}
Mentoring preservice teachers in collaborative instructional practices with public school partners has been a proven and substantiated way to improve their executive functioning and self-regulation skills. This study explores whether a contextually developed set of active-learning simulations in the lecture portion of a teacher education service-learning course can further improve preservice teachers' efficacy in the field. Using mixed-methodology, findings show how preservice teachers respond differently to styles of traditional lecture-style recitation and active-learning simulation and how that translates to working with middle school students. Data shows teachers feel more supported, confident, and positioned for success when engaged with authentic teaching simulations that challenge their approach to be effective managers of diverse student behavior.
\end{abstract}

Keywords: service-learning, active-learning, simulation, critical thinking

\section{WHAT IS TEACHER EFFICACY?}

The research presented in this study rests upon tenets of teacher efficacy. Teacher efficacy is based upon the work of Bandura $(1977,1986)$ who purports that efficacy beliefs affect human agency in various ways, including people avoiding tasks and not putting forth effort where they do not feel comfortable and confident. Efficacy affects emotional reactions and choices, such that people with low efficacy attribute difficulty to lack of ability rather than viewing effort as a way to overcome that difficulty. Additionally, people tend to avoid situations where they feel they cannot succeed. Thus, levels of efficacy affect how teachers interact with students and the amount of effort teachers are willing to put forth in meeting student needs and educational outcomes.

Bandura (1977) defined self-efficacy as "beliefs in one's capability to organize and execute the course of action required to produce given attainments" (p. 3). He argued that four external experiences or selfperceptions contribute to the development of self-efficacy: mastery experiences, modeling or vicarious experiences, social persuasion, and emotions or physiological factors such as fatigue, fear, and pain. Teaching efficacy refers to the teacher's belief in his or her ability to influence learning, even among students "who may be difficult or unmotivated" (Guskey \& Passaro, 1994, p. 4). Researchers typically distinguish between two dimensions of teaching efficacy: Personal Teaching Efficacy, the belief that teachers themselves can be effective in reaching personal teaching goals and outcomes regardless of educational obstacles, and General Teacher Efficacy, the belief that teachers as a whole (and the education system in general) can be effective in accomplishing student learning and reaching educational outcomes (Armor et al., 1976). 
Henson et al., (2001) concluded that a strong sense of efficacy is perhaps "one of the best documented attributes of effective teaching" (p. 404). Highly efficacious teachers have students who learn more and are more motivated (Shahid \& Thompson, 2001; Tschannen-Moran et al, 1998), have higher levels of enthusiasm and are more apt to implement instructional innovations (Woolfolk-Hoy \& Davis, 2006; Ghaith \& Yaghi, 1997), and are more likely to remain in the profession (Henson, 2001). Schwarzer and Hallum (2008) found that low general self-efficacy led to job stress and burnout, especially for teachers under the age of 40. Based upon their findings, they offer the recommendation that, "Strengthening teachers' optimistic self-beliefs along with improved teaching skills should be a preventative measure to avoid this downward spiral" (p. 169).

\section{LECTURE VS. ACTIVE LEARNING STYLES OF TEACHING}

Teachers are no doubt a critical component for student growth and development but it remains unclear as to what determines effective teaching. It may make sense for some disciplines (or courses) to utilize a particular style of instruction over another depending on the goals of the course or program. For example, if the goal of a medical terminology course is to teach definitions used in the various fields of medicine, then an informative lecture of terms and memorization might lead to a more broad and familiar understanding of language used throughout the profession. For this reason, lectures are an inherently popular and efficient style of instruction used to relay organized bodies of knowledge. Conversely, ActiveLearning is generally defined as students being more directly involved in the learning process using questioning and discussion in order to develop higher order thinking skills as it relates to the goals of the course. Students are encouraged to be more self-directed, no longer just passively receiving information from the instructor, and interact and apply concepts in divergent and meaningful ways. This style of instruction may be more popular with professions steaped heavily with complex human interactions such as counseling, teaching and coaching.

In 2005, The Council for Industry and Higher Education created the International Employer Barometer which surveyed 233 large multinational and small companies across a range of social and technical skill (Kubler \& Forbes 2005). Results showed that college graduate "skills" such as communication and the ability to work in teams were the most important and sought-after aptitudes by employers. Three out of four organizations ranked thoughtful analysis and decision-making skills as most important for the future (Archer \& Davison, 2008). To that end, a national focus on implementing evidence-based teaching practices that improve the quality of content-delivery in university coursework has been promoted by the National Research Council (2012). The organization has called attention to the benefits of active-learning pedagogies as best practices that promote growth and improve student learning, particularly those from underrepresented backgrounds (Theobald et al., 2020; Eddy \& Hogan, 2017; Prince, 2013).

Although the practice and development of active-learning strategies has received overwhelming support, studies have shown that university instructors spend 65 to 80 percent of class time lecturing to a passive student audience with little or no focus on group development, problem-solving and hands-on learning (Denaro et al., 2021; Deligkaris \& Chan Hilton, 2020; Lammers \& Murphy, 2002). Furthermore, research has shown that lectures are not the most effective ways to promote thought, change attitudes or develop behavioral skills (Tomkin et al., 2019; Darling-Hammond et al., 2017; Jackson, 2015). Freeman et al. (2014), showed that active learning not only leads to higher grades and performance on exams, but also showed that failure rates under traditional lecturing practices increased 55\% moreso than instructional practices utilizing active learning strategies.

\section{SERVICE-LEARNING IN TEACHER EDUCATION PROGRAMS}

In 1996, the National Commission on Teaching and America's Future issued a call to strengthen teacher preparation programs through a variety of reforms, including deeper candidate participation in clinical experiences. Since that time, teacher education programs have made significant headway with "creating stronger clinical practice, strengthening coursework around critical areas... and connecting coursework 
directly to practice in more extensive practice settings" (Darling-Hammond, 2010, p. 36). More and more, teacher preparation programs are requiring clinical experiences directly tied to coursework that engage preservice teachers with authentic teaching and learning collaborations, partnerships, and mentoring programs (Huang, 2006; Darling-Hammond, 2000).

One strategy for linking teacher education coursework with field experiences is called service-learning. Furco (2001) defines service-learning as "a teaching strategy that enhances students' learning of academic content by engaging them in authentic activities in which they apply the content of the course to address identified needs in the local and broader community." (p. 67). Service-learning can be viewed as a hybrid space where academic knowledge and experiential learning are brought together in ways that are more collaborative by nature and less hierarchical (Galvan \& Parker, 2011; Zeichner, 2010). Teacher education experts have argued that service-learning can expose preservice teachers to new situations that could occur on the job, uncover obscure assumptions that might interfere with their ability to effectively teach all students, and engage them in solving real-world problems with professional and experienced consultants (Baldwin et al., 2007). In effect, service-learning creates opportunities for students and faculty to question, analyze, and process timely challenges occurring in the field.

Although the practice of service-learning in teacher education has become widespread, the number of faculty who understand how to use the pedagogy skillfully is relatively small (Potthoff et al., 2000). This is in part due to the limited empirical basis for best practices as well as having to overcome several obstacles that may preclude its implementation. For example, one of the most common hurdles university faculty face is a lack of time to plan and implement high quality service-learning experiences that require wideranging leadership and detailed coordination with community partners (Tice \& Nelson, 2015; Nelson et al., 2012; Hondagneu-Sotelo \& Raskoff, 1994). Successful attempts at implementing service-learning in physical education settings have shown positive results such as promoting personal and social responsibility (Richards et al., 2018), and program sustainability (Garcia-Rico et al., 2021).

\section{SERVICE-LEARNING AND TEACHER EFFICACY RESEARCH}

There is a tranche of research showing the positive effects of service-learning on preservice teachers' development (Chiba et al., 2021). Much of this knowledge stems from measuring students' perceptions about teaching within school settings and examining how these experiences yield teaching skills, confidence, and sense of increased efficacy towards teaching (Brown et al., 2021). For example, teaching candidates in a literacy course in which students applied literacy teaching skills at an elementary school for low performing and diverse students made greater gains in self-efficacy and were more apt to implement course content than their counterparts in the same course who did not apply service-learning (Wasserman, 2009). Drawing upon the works of Bandura (1977), Wasserman attributed these differences to the greater mastery learning experienced by service-learning students. Cone (2009) conducted a similar study in which teacher candidates in one course participated in service-learning (leading inquiry-based science lessons for low-income minority elementary students in a community center), and candidates in a parallel course implemented inquiry-based science lessons with their peers. Candidates who participated in the servicelearning experience made significantly greater gains in their sense of efficacy to provide equitable science teaching. Kirtman (2008) also found similar increases in self-efficacy in teacher candidates centered on their understanding and confidence to teach mathematics, and Todd \& Brinkman (2008) reported the same type of self-efficacy gains in teacher candidates teaching social studies.

While service-learning is associated with increased teaching efficacy among preservice teachers, contextual variables surrounding the experience have been found to moderate its effects. For example, in a study of preservice teachers from nine teacher education programs, Root et al. (2002) found gains in teaching efficacy only among candidates who reported support for their efforts, including adequate training for tasks and assistance from an instructor (or a placement supervisor) in adjusting to the service-learning condition. Increased teaching efficacy was also linked to receiving more instruction in service-learning as a teaching method and having responsibility for implementing service-learning during a practicum or student teaching. 
There is little doubt that service-learning is a promising pedagogy for effective field experiences in teacher education. However, poorly designed and/or inappropriately managed service-learning experiences characterized by a lack of planning and preparation, insufficient guidance and direction from faculty, or working with non-supportive community partners can undermine candidates' feelings of teaching efficacy (Tice $\&$ Nelson, 2015). These issues point to the importance of preparing preservice teachers before, during, and after they engage in a course related service-learning project so they are more apt to be successful and make gains with teaching outcomes (Abrami et al., 2008).

\section{COURSE ATTRIBUTES}

There is overwhelming support that experiential learning is a "paradigm of noteworthy learning" that supports multiple learning objectives of learners and shapes their knowledge through experience (Abeysiriwardhane et al., 2021). One of the most widely shared features of effective professional development are related to how training practices incorporate simulations to engage preservice teachers directly in designing and trying out new teaching strategies, thus providing them opportunities to engage in the same style of learning they are designing for their students (Ge \& Wang, 2021). Such professional development uses authentic artifacts, interactive activities, and other strategies to provide deeply embedded, highly contextualized professional learning (Darling-Hammond et al., 2017). This approach moves away from traditional "lecture-style" models and focuses more on problem-based K-12 student teaching interaction.

For over a decade, we have studied the service-learning projects of an undergraduate physical education capstone course for prospective teachers (Tice \& Nelson, 2019; 2015; Nelson et al., 2015; Nelson et al., 2008). The service-learning experiences have provided students opportunities to work and teach with minority youth from neighborhoods characterized by low-performing schools, poverty, and gang recruitment. We have used mixed methods approaches in determining 1) whether preservice teachers would experience gains in efficacy beliefs, or confidence, throughout the service-learning experiences of the course and 2) factors that seem to play a role when service-learning fosters efficacy beliefs of preservice teachers. The longitudinal aspect of this research has made it possible to not only document the promises and pitfalls of service-learning field experiences, but also synthesize and substantiate a model that can guide the planning and implementation of community field experiences in teacher education coursework.

For this study, we hypothesized that an active-learning simulation sequence focused on engaging preservice teachers with problem-based learning linked to a course required service-learning component would more effectively cultivate a sense of teacher efficacy than traditional lecture-style instruction. We expected that the process of addressing real discernible problems, while receiving strategies and solutions on how to address those problems, would reinforce the higher order thinking skills necessary to interpret and analyze similar problems encountered in the service-related coaching experience. The question then becomes: does a strategically developed simulation sequence improve preservice teachers' sense of efficacy when engaging in service-learning; and if so, in what ways?

\section{RESEARCH DESIGN: ROLE-PLAYS, CASE STUDIES, AND SMALL GROUP DISCUSSIONS}

Participants of this study $(\mathrm{N}=100)$ were senior-level student teachers from a large diverse urban research university enrolled in a Teaching Secondary Physical Education Methods course. A quasiexperimental nonequivalent groups design was used where the instructor taught two semesters of the course "Lecture-Style" and two semesters of the course using "Active-Simulation" during class meetings. All four semesters of data collection included the same service-learning project (i.e., co-coaching an after-school soccer program that required 60-70 hours of direct instruction, design, and management of middle school students at practices after-school and games on Saturdays). Each pair of preservice coaches worked with 20-35 (mostly Hispanic) participant groups at different schools. All coaches were trained on basic soccer content and project expectations at the outset of each semester. 
The two "Lecture-Style" semesters utilized the presentation of pedagogy and management material using PowerPoint slides and multiple-choice exams based on a popular secondary physical education methods textbook (Note. All active-learning strategies the instructor would have normally incorporated into the course were intentionally left out of instruction these two semesters. There was minimal guidance and instruction related to the hours and local experience students needed to complete the coaching project). The following two semesters of the course focused less on textbook lectures and incorporated nine 50-minute active-learning simulations based on Role-Plays, Case Studies, and Small Group Discussions. The effectiveness of these active-learning strategies is heavily documented in the literature as leading to the development of higher order thinking skills such as problem-solving and critical thinking (Bean, 2011; Paul \& Elder, 2009).

In each of the active-learning simulations, students were placed in pairs or small groups, provided with vignettes, case studies, or problematic situations, directed to analyze and discuss the cases, and then roleplay possible solutions. Cases were not contrived, rather based upon actual authentic teaching situations and challenges that had taken place during previous semesters of the same course and same service-learning project, and thus conform to Bean's (2011) definition of a good case: "Good cases generally tell a real or believable story, raise thought-provoking issues based on conflict, lack of obvious or clear-cut answer, and demand a decision reached through critical thinking and analysis" (p. 159). After reading and discussing the original cases, students were asked to write (individually and as a group) what they wanted to accomplish in the role-plays, including the exact words and techniques to be used to address the situation. Moore (2014) argued that, "Role-playing unfamiliar or disorienting perspectives or imaging 'what if' situations makes an excellent critical thinking exercise" (p. 156). Role-plays were repeated so that multiple preservice teachers could try out their own solutions and other students could see different approaches to solving problems. Opportunities afforded by the role-plays included the ability to take a timeout from action, consider multiple angles and solutions, and rethink how to approach a particular situation. The postrole-play discussions were preplanned, detailed, in-depth, and explored how their classmates and professors reacted to the differing solutions to the challenges presented.

\section{EXAMPLE "ROLE-PLAY” SIMULATION}

Directions: Students read the vignette and take a few minutes to write down key points about how they should handle the situation and accomplish a reasonable outcome. Students are then paired up so that each takes a role and works through each key point (Note. instructor can stop in the middle of this analysis to check in with how the student or teacher feels in that role). Facilitator then calls up two people from the class to play the role of the student and the teacher from the vignette (Note. the teacher role can have one or more helpers in their ear to offer suggestions if they get stuck). Once this role-play has been worked through adequately, the facilitator leads a discussion of what worked well and what didn't go so well and why. The facilitator may invite two more preservice teachers to engage the roles again and again until all the participants find multiple solutions acceptable to their "teaching style". Students may take notes on what worked well and examine how different approaches and styles might work best for their temperament and note any traits that will help them become more successful in handling these types of situations in the future. Finally, the instructor summarizes, reemphasizes, and shares the talking points brought up throughout the process.

You are a substitute teacher and have been called in this morning to cover Mr. Daniels PE classes for the rest of the semester (about 3 weeks) at Eagle Lake High School. There were no lesson plans left for you. Fifth period rolls around where juniors and seniors enter the gym for a class called "Team-Sports". They tell you they have been playing a flag-football unit and a few students immediately enter the equipment closet and pull out the necessary equipment. A senior named Dominick divides up teams and runs the class very efficiently leaving you very little time and opportunity to manage and/or control anything. The game begins and Dominick exhibits extremely aggressive behavior towards the opposing team - hitting students hard and tripping and tackling them to the ground violently. He is also abusive to his own teammates yelling at them when they make 
a mistake and blame them for anything that goes wrong on their team. It is obvious the students are afraid of him and will do anything to try and just appease him and/or stay out of his way. You ask Dominick to speak with you in the office. What is your next move?

Summary Talking Points:

- STAY CALM ALWAYS! Have confidence \& use good eye-contact (and even ask for eye-contact back if necessary to emphasize the seriousness of the situation). Acknowledge his motivation level and skilled level of play (being punitive may make matters worse... at least until you get to know him better). Don't engage him emotionally/confrontationally, rather be assertive using "I" statements like "Here's what I think... Here's what I would like you to do...".

- Show respect and empathy by asking questions and trying to understand his perspective and situation. Students need to see that you care and have passion for them and their development. If necessary, try to get "buy in" by asking what he would like to do and negotiate alternative roles/responsibilities... Perhaps ask him to take on another task (i.e. referee, assistant coach, statistician, etc.). Constant caring on a consistent basis goes a long way eventually.

- Perhaps video the behavior and have him watch it with you in conference... Help him understand that the consequences of his actions could lead to injury of others (physical and/or psychological). This could also lead to bigger problems (civil action by other students' parents, suspension from school, etc.).

- Remind him of the Golden Rule- "Do unto others as you would have them do unto you."

- Set expectations and get agreement. Give him simple goals to work on with 1 or 2 outcomes or cues. Also, go over these expectations routinely (with him and the class) and post these social responsibility rules around the gym (See Don Hellison's work on promoting social responsibility through physical activity):

○ http://davidpetersoneportfolio.weebly.com/uploads/1/0/5/4/10549140/pe_workshop.pdf

- http://www.pecentral.org/climate/january99article.html

- Make it about fun for everyone... Team-work! Try to make health connections for improving his behavior.

- Modify the flag-football rules/equipment of the game to minimize opportunities for inappropriate behavior and harm.

- If need be, buy some time to ask other teachers/colleagues' advice in order to be confident in your approach, strategy and goals. Present alternative (better fitting) opportunities (e.g., Football Team)... Perhaps you can request he get moved to athletics instead of PE as a "better fit" for him?

\section{MEASURING TEACHER EFFICACY AND DATA ANALYSIS}

To measure senses of efficacy, preservice teachers participating in this study responded to the Teacher Efficacy Likert Scale (Tschannen-Moran \& Woolfolk-Hoy, 2001; Woolfolk \& Hoy, 1990) at the beginning and end of each semester of the course. This scale is designed to measure Personal Teaching Efficacy (PTE) and General Teacher Efficacy (GTE). Example questions on the PTE scale included: (1) When a student does better than usual, many times it is because I exert a little extra effort; (2) If one of my students couldn't do a class assignment, I would be able to accurately assess whether the assignment was at the correct level of difficulty; and (3) My teacher training program and/or experience has given me the necessary skills to be an effective teacher. Example questions on the GTE scale included: (1) The hours in my class have little influence on students compared to the influence of their home environment; (2) Teachers are not a very powerful influence on student achievement when all factors are considered; and (3) Even a teacher with good teaching abilities may not reach many students.

A confirmatory factor analysis (using squared multiple correlations on the diagonal and the PA2 extraction option in SPSS) was computed to substantiate the two dimensions of the Teacher Efficacy instrument. The two factors were uncorrelated $(r=.017)$ and accounted for $37 \%$ of the total variance. These findings are similar to other validity investigations of the Teacher Efficacy Scale (Denzine et al., 2005). A 
Cronbach's $\alpha$ coefficient of .79 was computed for scores on twelve PTE items, while Cronbach's $\alpha$ coefficient of .72 was computed for eight GTE items indicating high internal reliability for both dimensions of efficacy. Two items did not load at .40 or higher on either scale and were discarded for analysis. A repeated measures multivariate analysis was used to test for differences in PTE and GTE due to time (presurvey vs. post-survey) and experimental (active-learning simulation) vs. control (traditional lecture) condition. To partial out the effects of differences between scores on the pretest, an ANCOVA statistic was applied to the analysis when testing for between group variances (i.e., using pretest scores as a covariate).

A naturalistic approach (Lincoln \& Guba, 1985) was also used to collect data in the form of studentcentered focus groups, individual student journal reflections, and a culminating written self-evaluation. Focus groups with a representative sample of particpants each semester was conducted by an independent representative from the provost's office at three separate times spaced evenly throughout the semester. Questions regarding the extent to which students were actively engaged in the learning process were discussed. Individual journals were used to record students' personal feelings about their experiences during both the coursework and the service-learning components of the course. The self-evaluation was an openended culminating reflection about what students liked and disliked about the course, how they changed or transformed as a result of the course experiences, and how they would assess their own performance and extent to which they engaged the teaching and learning opportunities. To increase trustworthiness, all sources of qualitative data were recorded, transcribed, and analyzed, noting all salient and recurring units of meaning relevant to the course conditions and active-learning intervention.

\section{QUANTITATIVE RESULTS}

Results showed a significant main effect for time, with the posttest scores being higher than the pretest scores in both Personal Teaching Efficacy (PTE) and General Teacher Efficacy (GTE) for both control and experimental groups (Table 1). In the case of GTE, there were no significant differences $[\mathrm{F}(1,98)=.000$, $p=.985]$ between control and experimental group gains (Figure 1). However, in the case of PTE, there was a significant difference $[\mathrm{F}(1,98)=8.741, p=.004]$ between conditions where the experimental group reported significantly higher mean scores than the control group (Figure 2).

TABLE 1

TEACHER EFFICACY SCORES BY TIME AND CONDITION

\begin{tabular}{|c|c|c|c|c|c|c|c|c|}
\hline Scale & Condition & $\mathbf{N}$ & $\begin{array}{l}\text { Pre-Tes } \\
\text { Mean }\end{array}$ & $S D$ & Post-Test & $S D$ & $\begin{array}{l}\text { Time } \\
\text { (Pre-Post) } \\
\text { (F) }\end{array}$ & $\begin{array}{l}\text { Time * } \\
\text { Condition } \\
(F)\end{array}$ \\
\hline \multirow[t]{3}{*}{$\overline{\text { PTE }}$} & Control & 49 & 51.43 & 6.63 & 52.94 & 6.72 & & \\
\hline & Experiment & 51 & 53.14 & 6.03 & $\mathbf{5 7 . 3 5}$ & 5.70 & & \\
\hline & Total & 100 & 52.30 & 6.36 & 55.19 & 6.58 & 39.151* & 8.741* \\
\hline \multirow[t]{3}{*}{ GTE } & Control & 49 & 30.88 & 4.89 & 32.35 & 4.40 & & \\
\hline & Experiment & 51 & 32.43 & 6.04 & 33.92 & 7.70 & & \\
\hline & Total & 100 & 31.67 & 5.54 & 33.15 & 6.33 & 7.653* & .000 \\
\hline
\end{tabular}

* Significant at the $p<.05$ level 
FIGURE 1

GENERAL TEACHER EFFICACY GAINS BY CONDITION

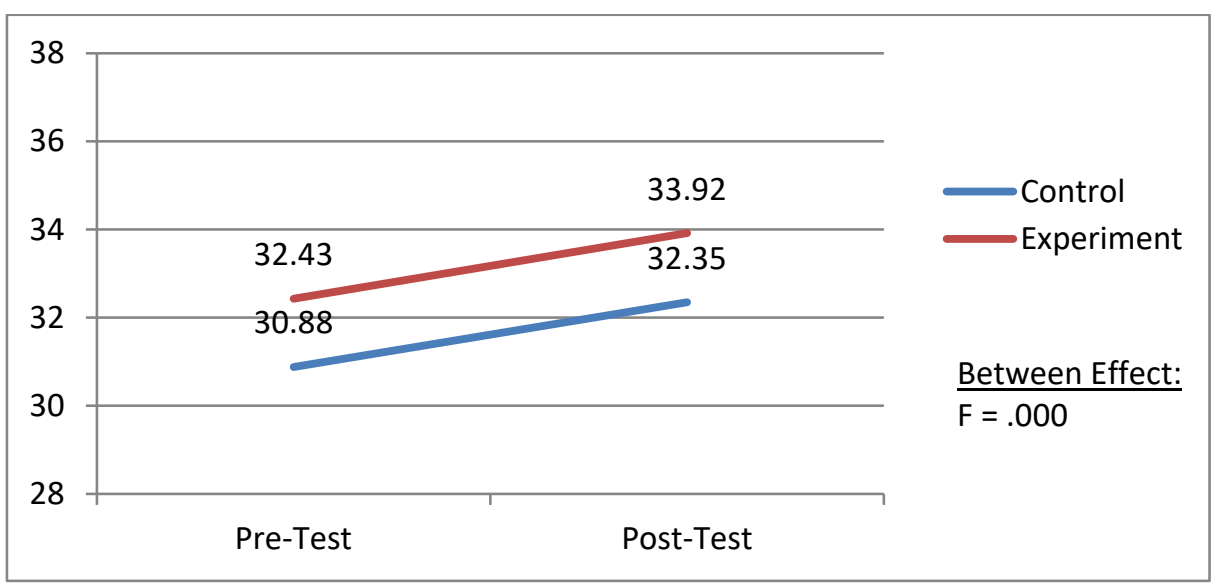

FIGURE 2

PERSONAL TEACHING EFFICACY GAINS BY CONDITION

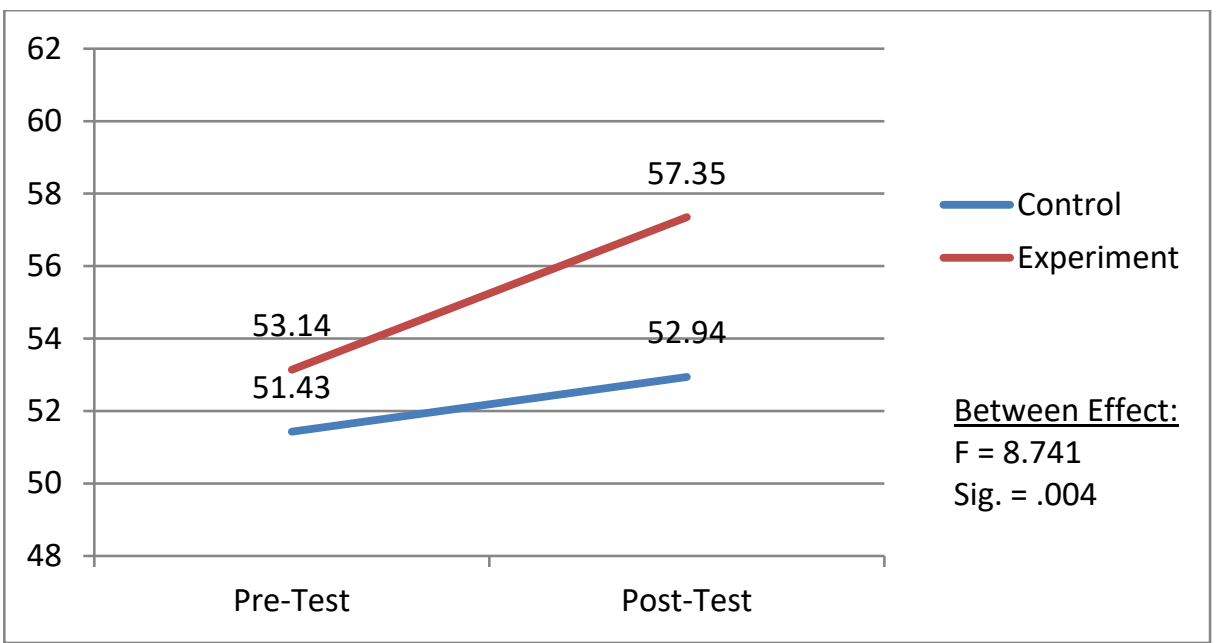

\section{QUALITATIVE RESULTS}

Qualitative findings yielded support for the active-learning strategies by delineating more clearly ways the active-learning experiences fostered gains in efficacy. The overarching emergent theme encompasses the link between the experience of participating in contextualized active-learning simulations and improved self-efficacy when it comes to engaging $7^{\text {th }}$ and $8^{\text {th }}$ grade students during the soccer program. The following two examples help demonstrate how the active-learning scenarios fostered self-assessment and the generation of alternative solutions for handling coaching situations:

"At first, I was a little apprehensive about the role-play vignettes but they did make me think about how I would react to those kinds of circumstances and if my first instincts would have been the right thing to do. I have realized I have a weakness with unfairness, wrong behavior, and confrontation." 
"The role-play activities were similar to some of the issues I encountered during coaching. Figuring out solutions to likely problems and learning new tips for dealing with these kinds of issues really improved my ability to handle these types of situations when they happened. I have more confidence that I can handle difficult situations when they arise."

The following four examples describe ways in which the active-learning scenarios offered insights into the varying responses to encountering challenging classroom situations and the opportunity to practice responding in safe and divergent ways:

"The class discussions really opened my eyes to different ways of handling tough situations that can occur in a school setting. I realize there are many ways of addressing students and that I have a huge weakness with dealing with hostile students. It was nice to get a chance to run through these scenarios in a lab-like setting because I have a much better idea how to manage students who have little to lose."

"The group activities showed me that I need to do a better job pausing for a moment and really think through how I go about reaching my goal. Typically, I would just command a behavior and tell my players what to do without stopping to think things through. I realize now that I need to focus more on the goal and see the situation as an opportunity to teach a lesson and not allow my knee jerk emotions and frustrations to overtake the goal along the way."

"Watching others handle tough situations was the most useful part. I remember several of us saying to ourselves, Oh, I would have never thought to say that or handle things that way... or that was handled well. I remember complimenting after class one day, telling him I enjoyed the way he handled that situation, how professional he was about it, and how it got me thinking about how I might do things differently."

"Role-play gets you closer to the real deal rather than just listening to someone tell you how to do it. It was never boring; I was always eager to see how different people would respond. I looked forward to seeing all the different techniques played out. I feel like it forces you to respond quickly while thinking critically, so you have to be on your toes in class. You know you are eventually going to have to step up there and try your solution out, so you can't just sit back and not pay attention to what is going on."

\section{DID THE ACTIVE-LEARNING SEQUENCE IMPROVE TEACHERS EFFICACY WITH SERVICE-LEARNING?}

The purpose of this study was to explore the impact of using simulations in a teaching methods course that relate to service-learning and preservice teachers' sense of efficacy. While there were no significant differences in efficacy gains when it comes to general perceptions about the teaching profession, the active learning simulations did likely provide an additional benefit to coaches working in the field. The significant increase in gains on the Personal Teaching Efficacy scale indicate that problem-based classwork designed to supplement a long-standing course-related service-learning project contributed to preservice teachers' confidence about their ability to positively impact student learning. The authentic nature of the simulations where preservice teachers take more implicit responsibility for what they are likely to encounter in their service-learning interactions provided opportunities to recognize for themselves what strategies are likely to work best and that what they did mattered.

These findings can be interpreted in light of the sources of efficacy beliefs identified by Bandura (1977). It seems likely that the course simulations and service-learning component provided preservice teachers with mastery experiences, which Bandura notes is the most influential source of efficacy beliefs. It can be 
argued that preservice teachers were unsure of their ability to positively impact service-learning, but as they participated in the course and engaged in the training vignettes, they received additional support from class members, course instructors and community partners. Coaches knew that middle school students were counting on them, and their confidence was bolstered when they saw themselves experience relevant success (and development) with classroom simulations. This mastery is further solidified and translated when preservice teachers get to use these new found strategies during the 60-70 hours of work simultaneously coaching youth. Finally, preservice teachers were consistently able to see their classmates engage in teaching on a regular basis and experience success, which provided vicarious experiences as an additional source of efficacy beliefs.

The failure to find greater gains in General Teacher Efficacy may have occurred because the focus of the case studies, role-plays and discussions were built more on individual solutions and accomplishments as opposed to solutions that could be used by the teaching profession in general found in a textbook. The lower level of gains in GTE (as compared to the greater PTE gains) also could be attributed to the negative perception of what teachers in general are able to achieve. These findings may provide additional support for educating to individual strengths and differences as well as adding provision for Darling-Hammond et al. (2017) call for teaching strategies that use authentic interactive activities that are deeply embedded and highly contextualized for learning.

\section{IMPLICATIONS AND DIRECTIONS FOR FUTURE RESEARCH}

Because many university classrooms do not operate from a shared understanding that professional learning is more a process of experience rather than a product of information, traditional instructional practices have come under scrutiny. Questions about the executive functioning and self-regulation skills of college graduates continue to be on the rise and university administrators are scrambling to provide support for faculty that encourage active-learning and service-related strategies (Kaplan \& Berman, 2010). To improve active-learning practices for faculty, provosts' offices and learning-centers have created support mechanisms and special trainings for instructors that help promote student engagement and interactive learning with students (e.g., e-portfolios, mobile-based interactive tools, service-learning centers, self and peer-evaluation seminars, social networking platforms, mentoring programs, etc.). In teacher preparation programs, more early field observations and service-learning hours are being emphasized and required for program assessment, accreditation, and state licensure.

One factor that consistently emerges in our research relates to the ability of preservice teachers to deal with obstacles. Few young leaders feel confident in their ability to address difficult teaching situations and therefore seek out solutions that can transform teaching environments and learning. Future research is needed to document ways to help preservice teachers overcome these obstacles and improve their ability to respond to youth, and youth development, in positive ways. The hybrid nature of service-learning provides an excellent opportunity for a community of learners to support each other and provide ideas and knowledge about teaching and coaching, but the process is complex and requires inordinate coordination and support if to be successful. Future research can delineate more clearly the interdependence of factors that improve or impede these experiences. One factor worth exploring is how can we develop community partners to fully embrace and engage this hybrid training model. We are confident that changes in the actions of the community service-learning site (or site supervisors) can dramatically impact this training model and the efficacy outcomes of preservice teachers.

\section{CONCLUSION}

As concerns about producing effective teachers continue to grow, teacher education programs need to be acutely aware of how coursework, instruction, and training contribute to the development of preservice teachers' confidence and their ability to help students learn. The instructors of this study tried to do this by incorporating active-learning simulations into a teaching methods course in conjunction with a wellestablished service-learning component with school partners. While the combination of service-learning 
and methods coursework yielded increased confidence about teaching, it was the connection between classbased preparation for responding to challenges encountered in the service-learning experience that led to the greatest gains in Personal Teaching Efficacy. The results showed that the active-learning strategies used in the experimental condition helped preservice teachers feel more confident in their ability to promote student learning than did traditional lecture-style strategies. By planning how to handle specific situations, role-playing these techniques, and getting feedback from peers and professors afterward (and along the way), students may have learned that they could individually and effectively face school and classroom challenges in the field. Rarely do novice teachers get several trial "run-through" experiences that encourage mistakes without any real consequences for students. This study underscores the need for preserive teachers

to be immersed in learning experiences that go beyond textbooks and memorization so that teachers in training are prepared and feel prepared.

\section{REFERENCES}

Abeysiriwardhane, A., Lützhöft, M., \& Ghosh, S. (2021). Learning and learning-to-learn by doing: An experiential learning approach for integrating human factors into maritime design education. Maritime Technology and Research, 3(1), 31-48. https://doi.org/10.33175/mtr.2021.241912

Abrami, P.C., Bernard, R.M., Borokhovski, E., Wade, A., Surkes, M.A., Tamim, R., \& Zhang, D. (2008). Instructional interventions affecting critical thinking skills and dispositions: A stage 1 metaanalysis. Review of Educational Research, 78(4), 1102-1134. Retrieved from $\mathrm{http}: / /$ rer.sagepub.com/content/78/4/1102.short

Archer, W., \& Davison, J. (2008). Graduate employability. The Council for Industry and Higher Education. Retrieved from http://www.empscompacts.org.uk/resources/LincsandRutland/Grademployability.pdf

Armor, D., Conroy-Oseguera, P., Cox, M., King, N., McDonnell, L., Pascal, A., . . Zellman, G. (1976). Analysis of the school preferred reading programs in selected Los Angeles minority schools. Rep. No. R-2007-LAUSD. Santa Monica, CA: RAND. (ERIC Document Reproduction Service No. $130243)$.

Baldwin, S., Buchanan, A., \& Rudisill, M. (2007). What teacher candidates learned about diversity, social justice, and themselves from service-learning experiences. Journal of Teacher Education, 58(4), 315-327. Retrieved from http://jte.sagepub.com/content/58/4/315.short

Bandura, A. (1986). Social foundations of thought and action: A social cognitive theory. Englewood Cliffs, NJ: Prentice-Hall.

Bandura, A. (1977). Self-efficacy: Toward a unifying theory of behavioral change. Psychological Review, 84, 191-215. Retrieved from http://psycnet.apa.org/journals/rev/84/2/191/

Bean, J.C. (2011). Engaging ideas: The professor's guide to integrating writing critical thinking and active-learning in the classroom (2nd ed.). San Francisco, CA: Jossey-Bass.

Brown, A.L., Myers, J., \& Collins, D. (2021). How pre-service teachers' sense of teaching efficacy and preparedness to teach impact performance during student teaching. Educational Studies, 47(1), $38-58$.

Chiba, M., Sustarsic, M., Perriton, S., \& Edwards, B. (2021). Investigating effective teaching and learning for sustainable development and global citizenship: Implications from a systematic review of the literature. International Journal of Educational Development, 81 . https://doi.org/10.1016/j.ijedudev.2020.102337

Cone, N. (2009). A bridge to developing efficacious science teachers of all students: Community-based service-learning supplemented with explicit discussions and activities about diversity. Journal of Science Teacher Education, 20, 365-383.

Darling-Hammond, L. (2010). Teacher Education and the American future. Journal of Teacher Education, 61(2), 35-47.

Darling-Hammond, L. (2000). Teacher quality and student achievement: A review of state policy evidence. Education Policy Analysis Archives, 8(1), 1-44. 
Darling-Hammond, L., Hyler, M.E., \& Gardner, M. (2017). Effective Teacher Professional Development (fact sheet). Palo Alto, CA: Learning Policy Institute.

Deligkaris, C., \& Chan Hilton, A.B. (2020). COPUS: A non-evaluative classroom observation instrument for assessment of instructional practices. Retrieved October 1, 2019, from http://hdl.handle.net/20.500.12419/136

Denaro, K., Sato, B., Harlow, A., Aebersold, A., Verma, M. (2021). Comparison of cluster analysis methodologies for characterization of classroom observation protocol for undergraduate STEM (COPUS) data. Life Sciences Education, 20(1). https://doi.org/10.1187/cbe.20-04-0077

Denzine, G., Cooney, J., \& McKenzie, R. (2005). Confirmatory factor analysis of the Teacher Efficacy Scale for prospective teachers. British Journal of Educational Psychology, 75, 689-708. Retrieved from http://onlinelibrary.wiley.com/doi/10.1348/000709905X37253/abstract?deniedAccessCustomised Message $=$ \&userIsAuthenticated $=$ false

Eddy, S., \& Hogan, K. (2017). Getting under the hood: How and for whom does increasing course structure work? Life Sciences Education, 13(3), 453-468. https://doi.org/10.1187/cbe.14-03-0050.

Freeman, S., Eddy, S., McDonough, M., Smith, M, Okoroafor, N., Jordt, H., \& Wenderoth, P. (2014, June). Active learning increases student performance in science, engineering, and mathematics. Proceedings of the National Academy of Sciences, 111(23), 8410-8415. DOI: 10.1073/pnas.1319030111

Furco, A. (2001). Advancing service-learning at research universities. New Directions for Higher Education, 114, 67-78. Retrieved from http://onlinelibrary.wiley.com/doi/10.1002/he.15/abstract

Galvan, C., \& Parker, M. (2011). Investigating the reciprocal nature of service-learning in physical education teacher education. Journal of Experiential Education, 34(1), 55-70.

García-Rico, L., Martínez-Muñoz, L.F., Santos-Pastor, M.L., \& Chiva-Bartoll, O. (2021). Servicelearning in physical education teacher education: A pedagogical model towards sustainable development goals. International Journal of Sustainability in Higher Education.

Ge, X., \& Wang, Q. (2021). Cultivating Design Thinking in an Interdisciplinary Collaborative ProjectBased Learning Environment. In B. Hokanson, M. Exter, A. Grincewicz, M. Schmidt \& A.A. Tawfik (Eds.), Intersections Across Disciplines. Educational Communications and Technology: Issues and Innovations. Springer, Cham. https://doi.org/10.1007/978-3-030-53875-0_15

Ghaith, G., \& Yaghi, H. (1997). Relationships among experience, teacher efficacy, and attitudes toward the implication of instructional innovation. Teaching and Teacher Education, 13, 451-458. Retrieved from http://www.sciencedirect.com/science/article/pii/S0742051X96000455

Guskey, T.R., \& Passaro, P.D. (1994). Teacher efficacy: A study of construct dimensions. American Educational Research Journal, 31(3), 627-643.

Henson, R. (2001). The effects of participation in teacher research on teacher efficacy. Teaching and Teacher Education, 17, 819-836.

Henson, R., Kogan, L., \& Vacha-Haase, T. (2001). A reliability generalization study of the teacher efficacy scale and related instruments. Educational and Psychological Measurement, 61(3), 404420. Retrieved from http://epm.sagepub.com/content/61/3/404.short

Hondagneu-Sotelo, P., \& Raskoff, S. (1994). Community service-learning: Promises and problems. Teaching Sociology, pp. 248-254.

Huang, G.H. (2006). Fostering active-learning in a teacher preparation program. Education, 127(1), 3138.

Jackson, D. (2015). Employability skill development in work-integrated learning: Barriers and best practice. Studies in Higher Education, 40(2), 350-367. DOI: 10.1080/03075079.2013.842221

Kaplan, S., \& Berman, M.G. (2010). Directed Attention as a Common Resource for Executive Functioning and Self-Regulation. Perspectives on Psychological Science, 5(1), 43-57. https://doi.org/10.1177/1745691609356784

Kirtman, L. (2008). Preservice teachers and mathematics: The impact of service-learning on teacher preparation. School Science and Math, 108(3), 94-102. 
Kubler, B., \& Forbes, P. (2005). Student Employability Profiles: A Guide for Employers, Degrees of Skill. Council for Industry and Higher Education.

Lammers, W., \& Murphy, J. (2002). A profile of teaching techniques used in the university classroom: A descriptive profile of a US public university. Active Learning in Higher Education, 3(1), 54-67. https://doi.org/10.1177\%2F1469787402003001005

Lincoln, Y.S., \& Guba, E.G. (1985). Naturalistic inquiry. Beverly Hills, CA: Sage.

Moore, K.D. (2014). Effective instructional strategies: From theory to practice. Sage Publications.

National Research Council. (2012). Education for life and work: Developing transferable knowledge and skills in the $21^{\text {st }}$ century. Washington D.C.: National Academies Press.

Nelson, L.P., Crow, M.L., \& Tice, K. (2015). Using Active-Learning Strategies to Increase Pre-Service Teachers' Efficacy in a Service-Learning Course. International Journal of Research on ServiceLearning and Community Engagement, 3(1), 21585.

Nelson, L.P., McMahon, S., \& Torres, T. (2012). The impact of a junior high school community intervention project: Moving beyond the testing juggernaut and into a community of creative learners. School Community Journal, 22(1), 125-144.

Nelson, L.P., Tice, K.C., \& Theriot, S. (2008). Impact of service-learning on teachers' efficacy. Academic Exchange Quarterly, 12(3), 102-107.

Paul, R., \& Elder, L. (2009). Miniature guide to critical thinking concepts and tools (6th ed.). Dillon Beach, CA: Foundation for Critical Thinking.

Potthoff, D., Dinsmore, J., Stirtz, G., Walsh, T., Ziebarth, J., \& Eifler, K. (2000). Preparing for democracy and diversity: The impact of a community-based field experience on preservice teachers' knowledge, skills, and attitudes. Action in Teacher Education, 22(1), 79-92.

Prince, M. (2013). Does active learning work? A review of the research. Journal of Engineering Education, 93(3), 223-231. https://doi.org/10.1002/j.2168-9830.2004.tb00809.x

Richards, K.A.R., Ivy, V.N., Lawson, M.A., \& Alameda-Lawson, T. (2018). Teaching Personal and Social Responsibility in Physical Education Teacher Education: A Service-Learning Application. In Handbook of research on service-learning initiatives in teacher education programs (pp. 143162). IGI Global.

Root, S., Callahan, J., \& Sepanski, J. (2002). Building teaching dispositions and service-learning practice: A multi-site study. Michigan Journal of Community Service Learning, 8(2).

Schwarzer, R., \& Hallum, S. (2008). Perceived teacher self-efficacy as a predictor of job stress and burnout: Mediation analyses. Applied Psychology, 57(s1), 152-171. doi: http://onlinelibrary.wiley.com/doi/10.1111/j.1464-0597.2008.00359.x/pdf

Shahid, J., \& Thompson, D. (2001). Teacher efficacy: A research synthesis. Paper presented at the Annual Meeting of the American Educational Research Association. Seattle, WA, April 10-14. Retrieved from http://files.eric.ed.gov/fulltext/ED453170.pdf

Theobald, E.J., Hill, M.J., Tran, E., Agrawal, S., Arroyo, N., Behling, S., \& Freeman, S. (2020). Active learning narrows achievement gaps for underrepresented students in undergraduate science, technology, engineering, and math. Proceedings of the National Academy of Sciences USA, 117(12), 6476-6483. doi: https://doi.org/10.1073/pnas.1916903117

Tice, K.C., \& Nelson, L.P. (2019). Towards Understanding When Service-Learning Fosters Efficacy Beliefs of Preservice Teachers. Educating Teachers and Tomorrow's Students through ServiceLearning Pedagogy, pp. 105-120.

Tice, K.C., \& Nelson, L.P. (2015). Promises and pitfalls of service-learning in teacher preparation: Lessons from longitudinal research. In V.M. Jagla, A. Furco, \& J.R. Strait (Eds.), ServiceLearning Pedagogy: How does it measure up? Charlotte, N.C.: Information Age Publishing.

Todd, R., \& Brinkman, S. (2008). Service learning in a social studies methods course: Experience and place-based curriculum. The Educational Forum, 72, 79-91.

Tomkin, J., Beilstein, S., Morphew, J., \& Herman, G.L. (2019). Evidence that communities of practice are associated with active learning in large STEM lectures. IJ STEM Ed, 6, 1. https://doi.org/10.1186/s40594-018-0154-Z 
Tschannen-Moran, M., \& Woolfolk-Hoy. (2001). Teacher efficacy: Capturing an elusive construct. Teaching and Teacher Education, 17(7), 783-805. Retrieved from http://www.sciencedirect.com/science/article/pii/S0742051X01000361

Tschannen-Moran, M., Woolfolk-Hoy, A., \& Hoy, W. (1998). Teacher efficacy: Its meaning and measure. Review of Educational Research, 68(2), 202-248. Retrieved from http://www.sciencedirect.com/science/article/pii/S0742051X01000361

Wasserman, K.B. (2009). The role of service-learning in transforming teacher candidates' teaching of reading. Teaching and Teacher Education, 25(8), 1043-1050.

Woolfolk-Hoy, A., \& Davis, H. (2006). Teacher self-efficacy and its influence on the achievement of adolescents. In F. Pajares \& T. Urdan (Eds.), Self-Efficacy Beliefs of Adolescents.

Woolfolk, A., \& Hoy, W. (1990). Prospective teachers' sense of efficacy and beliefs about control. Journal of Educational Psychology, 82(1), 81-91. Retrieved from http://psycnet.apa.org/journals/edu/82/1/81/

Zeichner, K. (2010). Rethinking the connections between campus courses and field experiences in college- and university-based teacher education. Journal of Teacher Education, 61(1-2), 89-99. 